\title{
Quantitative analysis of social grooming behavior of the honey bee Apis mellifera carnica
}

\author{
J Božič *, T Valentinčič \\ Department of Biology, University Ljubljana, Večna pot 111, 61000 Ljubljana, Slovenia
}

(Received 4 November 1993; accepted 30 January 1995)

\begin{abstract}
Summary - We observed social grooming behavior in the Carniolan bee, Apis mellifera carnica. Bouts of grooming lasted up to $45 \mathrm{~s}$, and were directed to the wing axis (44.6\%), the petiolus (18\%) and the sternite regions of abdomen (2.8\%) of the receiving bee ( 41 bees). During grooming, the receiving bees held their wings perpendicular to the body axis. Groomer bees most often cleaned those body parts which could not be reached during self-cleaning by receiving bees. During $18 \%$ of the grooming time, groomer bees cleaned their own mouth parts and antennae. The grooming behavior removed dust and pollen from the wing bases and petiolus and realigned the body hairs. No attempts to remove Varroa mites were observed during self-cleaning or social grooming behavior.
\end{abstract}

social grooming / self-cleaning / grooming dance / Apis mellifera carnica / ectoparasite / Varroa jacobsoni

\section{INTRODUCTION}

The controversy of whether Apis mellifera $L$ can remove ectoparasites from their nestmates (Boecking et al, 1993) is unresolved. Wallner (1989), Ruttner and Hänel (1992) and Moosbeckhofer (1992) noted physical damage on the bodies of Varroa mites found in Apis mellifera colonies, which corresponded to the shape of the mandibles of honey bees. These authors concluded that honey bees of the Carniolan strain occasionally damaged the body of Varroa mites with their mandibles.
Bees possibly remove Varroa mites during social grooming behavior (Peng, 1988). Social grooming behavior is a cleaning behavior of bees directed at other bees in the hive (Haydak, 1929). During social grooming bees use their mouth parts to remove debris from the wing bases and other body parts of other bees. This behavior is elicited by a grooming dance performed by potential receivers of grooming behavior (Milum, 1947). The grooming dance involves rapid self-cleaning movements with the legs and waggling and bending of the body of the bees (Milum, 1947).

*Present address: Zoology Department, Louisiana State Unviersity, Baton Rouge, LA 70813, USA. 
This provokes social grooming behavior in temporarily specialized groomer bees, which often clean several other bees in a row (Kolmes, 1989). These specialized grooming bees perform the same grooming behavior repeatedly over a period of several days, during which time they rarely participate in other live activities (Kolmes, 1989).

Kolmes and Winston (1988) and Seely and Kolmes (1991) considered social grooming behavior as an essential element in the division of labor in a honey bee colony. No detailed analyses of releasing stimuli for grooming behavior, and no timing of grooming directed at different parts of the receiver bees has been reported to date. We videorecorded and analyzed social grooming behavior of honey bees and sought evidence for the removal of Varroa mites during these activities.

\section{MATERIALS AND METHODS}

The grooming behavior of honey bees ( $A$ mellifera carnica Pollm) was investigated in 2 observation hives. Varroa jacobsoni Oud mites were occasionally found in both observation hives ( $<5 \%$ infestation). The hives were located in shaded areas within experimental apiaries near Krško (autumn 1990) and near Ljubljana (spring 1991). Air temperatures in the apiaries were $18-28^{\circ} \mathrm{C}$. A $6 \times 4 \mathrm{~cm}$ area of the comb was videorecorded through the glass of the observation hive with a Sharp VHS camcorder. The social grooming behavior was analyzed from the first groomer/receiver interaction until the first patrolling behavior which lasted $>2 \mathrm{~min}$.

The duration of the grooming behavior ( 16 bees) and the grooming dance (34 bees) were determined by counting events on every fifth successive video frame. Fast movements of 10 grooming dancers were studied frame by frame. The left and right displacements of the petiole and the tip of the abdomen and their relative positions were compared for each successive video frame. Data are shown as frequency charts, medians and interquartile ranges, which were chosen in preference to means and standard deviations to correctly illustrate events which are not dis- tributed normally in time. Behavior transitions of grooming dancers were tested with goodnessof-fit $\chi^{2}$ test, and distributions of behavior sequence length were tested with Kruskal-Wallis test using SAS statistical software (SAS Institute Inc, 1988a,b).

\section{RESULTS}

Social grooming behavior is the cleaning behavior of bees in which they use their mandibles to remove debris and pollen from their nestmates. The waggling and twisting movements of the bees which solicit grooming care, known as the grooming dance, released the grooming behavior in some of the resting bees. A grooming dancer usually cleaned its own body before receiving grooming care of an attending groomer bee. After the groomer bee made the first cleaning attempts on the recipient bee, the recipient bee fully spread its wings. During this posture, which we called the social grooming display, the recipient bee was motionless with its abdomen lifted to expose the body to the grooming care. During social grooming behavior both the groomers and the receiving bees were mostly oriented upward (43 of 51 groomers and 39 of 51 recipient bees).

\section{Grooming behavior}

Regular groomers groomed up to 8 recipients one after the other without breaks larger then $2 \mathrm{~min}$. These regular groomer bees searched for new recipients among the nearest nestmates. Regular groomers responded immediately to the grooming dance behavior of neighbor bees. Seven grooming interactions of the regular groomer bees out of 58 were released by self-cleaning activities and grooming dances of the recipient bees.

The groomer bees found the next recipient bee after a median searching time of 
$6.5 \mathrm{~s}$ (3-15.5 s, interquartile range). The searching groomer bees palpated bees in their vicinity and tried to groom the contacted bees. They occasionally cleaned their own antennae with a single cleaning movement of the front legs. The grooming behavior was released after the recipient bee exposed its body in a grooming display. Fifty percent of the social grooming behavior of regular groomer bees lasted longer then $22 \mathrm{~s}$. On occasion 2 groomers groomed the same recipient bee.

Occasional and regular groomer bees cleaned body regions of the recipient bees closest to them. The duration of the grooming activity was $0.4-1.8 \mathrm{~s}$ (median values, (fig 1). In $75 \%$ of the observations, successive grooming activities lasted $<3 \mathrm{~s}$. The grooming behavior in the wing regions lasted
$44.6 \%$, in the petiole regions $18 \%$ (fig 2 ), and in the sternite regions of the abdomen $2.8 \%$ of the total grooming time. The groomer bees groomed the petiole region during 32 grooming displays, the abdominal tergites during 28 displays, the left wings' axis during 27 displays, the right wings' axis during 26 displays, the dorsal part of thorax during 19 displays and the head and the neck regions during 6 out of 42 grooming displays.

Between the successive grooming activities directed at the same bee (median duration $0.6 \mathrm{~s}$ ), the groomer bees brushed their own antennae and mouth parts with the first pair of legs (41 of 42 cases). The self-cleaning movements lasted shorter than the previous social grooming behavior (77 out of 88 cases). The groomer bees spent approx-
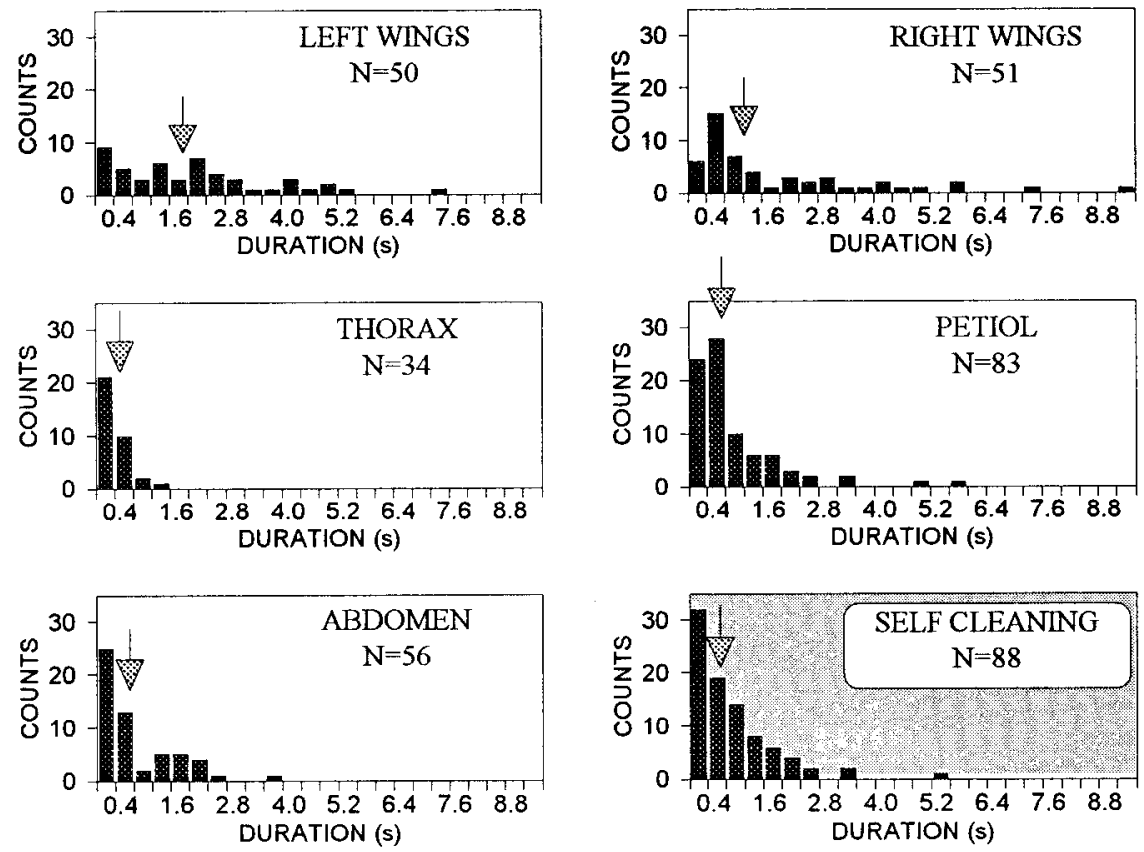

Fig 1. Frequency distribution of durations of grooming behavior directed at different body parts of the accessed bee (unshaded plots) and self-cleaning behavior (shaded plot). Arrows above bars indicate median values. Forty-one social grooming displays were analyzed. There was no significant difference between the durations of grooming the left and the right wings' axes (Kruskal-Wallis test: $\chi^{2}=0.646 ; P=0.42$ ). 


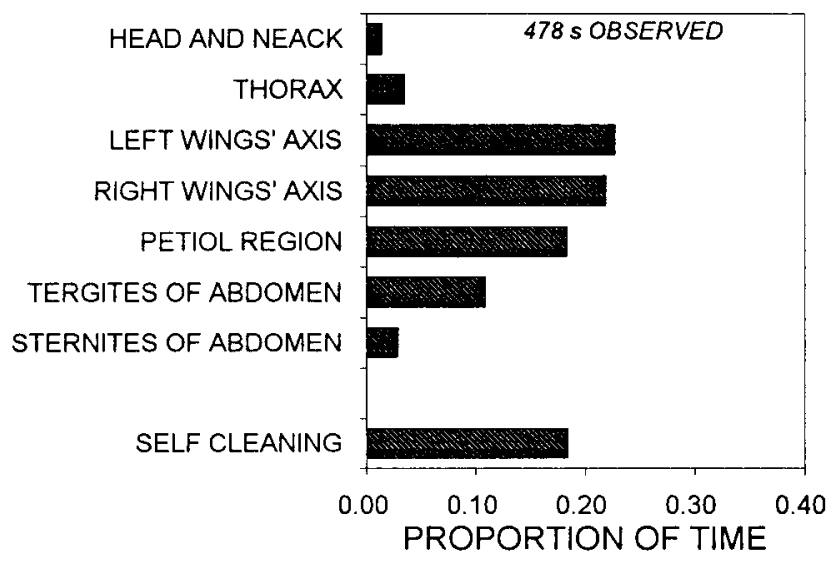

Fig 2. Proportions of time spent in grooming activities directed at different regions of honey bee body for 16 groomer bees which groomed 41 recipient bees. imately $18 \%$ of the total grooming time cleaning their own bodies (fig 2 ).

\section{Behavior of recipient bees}

The grooming recipients came from the resting population. Initially, resting bees that accepted grooming care did not spontaneously groom themselves and did not perform the grooming dance, whereas these same bees did groom themselves after being groomed by other bees. The bees that cleaned themselves and danced provoked grooming behavior in their nestmates. Before the grooming dance, the dancers usually cleaned their own bodies. They vigorously brushed the antennae, mouth parts, heads and thorax with any pair of legs and also brushed the surface of the abdomen with the hind legs. During the grooming dance, the dancers cleaned themselves with legs, and waggled and bent their bodies. Waggling movements are movements of head and abdomen in the same direction (105 cases), whereas twisting and bending movements are movements of head and abdomen in opposite directions (109 cases, 10 grooming dancers).

The grooming dance released grooming care in 23 of 32 cases. The 9 dancers that were not groomed, groomed themselves. The dancers that received grooming care did not rest and walk around after the dance; they either cleaned their own bodies or received additional grooming care from nest-

Table I. Behavioral sequence of the dancer.

\begin{tabular}{|c|c|c|c|c|c|c|}
\hline & 17 & & 17 & & 23 & \\
\hline Resting & $\rightarrow$ & Self- & $\rightarrow$ & Grooming & $\rightarrow$ & Grooming \\
\hline Patrolling & $<-\frac{1}{2}$ & Cleaning & $<-$ & Dance & $<-$ & Display \\
\hline
\end{tabular}

The numbers of transitions from resting and patrolling to grooming display were significantly different from numbers of transitions in the opposite direction (goodness-of-fit $\chi^{2}$ statistics: $\chi^{2}=23.23, P<0.001, d f=2 ; 32$ grooming dancers) 
mates. Some bees repeated the grooming dance after receiving the grooming care ( 9 out of 23 cases); other bees started resting and patrolling behavior (11 cases) and some bees cleaned their own bodies ( 5 cases). The most frequently repeated sequences of behavior patterns in the dancers were: resting and patrolling $\longrightarrow$ self-cleaning $\rightarrow$ grooming dance $\longrightarrow$ grooming display (table I).

The grooming dancers danced $20.8 \%$, self-cleaned $29.3 \%$ and showed social grooming display $31.3 \%$ of the time (30 $\mathrm{min}$ ). The grooming dances lasted $8 \mathrm{~s}$ (median). The median duration of a grooming behavior directed at a grooming dancer was $8 \mathrm{~s}$ whereas the median duration of a grooming behavior directed at a resting bee was $22 \mathrm{~s}$. After being groomed, the recipients usually shook (median shaking time 0.33 in 24 of 34 bees) and folded their wings to the normal backward position. Most of the wing shaking (21 of 24 cases) occurred after the groomers left the recipients. Satiation or lack of grooming stimuli were possible reasons for the end of the social grooming display.

\section{DISCUSSION}

Specialized groomers preferentially clean grooming dancers and to a lesser extent other resting bees (Blom, 1990). During the search for potential recipients, the groomer bees palpated nestmates. Possible releasers of grooming behavior are chemical and mechanical stimuli. Waggling and twisting of the body and self-cleaning movements of grooming dancers also stimulate groomers.

Self-cleaning behavior patterns included the cleaning of antennae and mouth parts with the first legs, the cleaning of the antenna cleaners and brushes on the first legs with cleaning spines on the middle legs, the cleaning of middle leg spines with brushes on the hind legs and finally the cleaning of the brushes between themselves to put the dust particles onto corbicula of the hind legs (Snodgrass, 1956; Winston, 1987). A bee that cleans its own body cannot reach the neck, petiole and wing bases with their own legs. Groomers most frequently bite and lick these unreachable regions of their nestmates (fig 2 ).

Removal of Acarapis dorsalis and $A$ externus mites from wings axis and petiole could be accomplished during the grooming behavior of both regular and occasional groomers. Peng (1988) and Büchler et al (1992) observed A cerana seizing Varroa mites with their mandibles. Out of 25 artificially infested worker bees ( $A$ mellifera), removal of Varroa mites was observed in 12 cases. However, there was no evidence that groomers grasped and removed the mites with their mandibles (Büchler et al, 1992). Varroa mites that do not settle between abdominal sternites can easily escape the mandibles by clinging to the body of groomers and other bees in the vicinity. Varroa mites often attach themselves between abdominal sternites and suck the hemolymph (Ritter and SchneiderRitter, 1988). These mites are not removed during grooming activity.

In our studies, only 5 groomers out of 42 groomed the abdominal sternites. We had a very little chance to observe defense behavior against Varroa in unselected experimental colonies with low Varroa infestation. During 2 years of observation not a single groomer bee was observed to seize and remove a Varroa mite from another bee. Removal of Varroa mites in A cerana bees is a result of vigorous cleaning movements, which was not observed in $A$ mellifera (Büchler et al, 1992). In A cerana, 2-4 bees usually groom a single nestmate whereas in A mellifera typically only one groomer per bee was observed. Two groomers cleaning the same nestmate were observed only in rare cases. Social grooming behavior and chemical stimuli which release vigorous cleaning behavior need to be investigated 
further in our attempts to discover a natural mechanism to lessen the danger of Varroa infestations.

\section{ACKNOWLEDGMENTS}

We appreciate the help of $\mathrm{J}$ Woodring and $\mathrm{J}$ Harris for critical reading of the manuscript. This work was supported by Slovenian Ministry of Education grant to JB and Slovenian Ministry of Science and Technology grant P1-0114-487 to TV.

Résumé - Analyse quantitative du comportement social de toilettage chez l'abeille Apis mellifera carnica. Le toilettage social chez l'abeille mellifère est considéré comme un élément essentiel de la division du travail au sein de la colonie (Kolmes et Winston, 1988 ; Seeley et Winston, 1991). Au cours du toilettage social chez Apis cerana, les abeilles débarrassent leurs congénères des acariens Varroa jacobsoni (Peng, 1988 ; Büchler et al, 1992). Nous avons examiné si $A$ $m$ carnica était susceptible d'ôter les varroas par toilettage. Pour cela nous avons étudié les stimuli qui déclenchent le comportement de toilettage et la durée des activités de toilettage sur les diverses parties du corps de l'abeille receveuse. Le comportement de toilettage social a fait l'objet d'enregistrements vidéo que I'on a analysés en les repassant en continu et image par image. Le toilettage social comporte 2 phases, l'approche par la toiletteuse d'une receveuse potentielle et l'activité de nettoyage. La proposition de toilettage est acceptée lorsque la receveuse montre une attitude de toilettage caractérisée par les ailes ouvertes perpendiculairement à l'axe du corps. Les abeilles qui à l'origine se nettoyaient elles-mêmes et effectuaient la danse de toilettage sont abordées plus tard par les toiletteuses. Au cours de la danse de toilettage les abeilles frétillent et se tortillent. Les danses de toilettage sont aussi effectuées par certaines abeilles au repos et certaines abeilles qui patrouillent dans le nid. La séquence comportementale la plus fréquente de la danseuse est : repos et patrouillage $\rightarrow$ autonettoyage $\rightarrow$ danse de toilettage $\rightarrow$ attitude de toilettage (tableau I). La durée d'une séquence typique de danse-toilettage est de 6,5-12 s (valeurs médianes). Les abeilles toilettent à la file un maximum de 8 congénères sans s'interrompre. Entre 2 approches successives de toilettage (valeur médiane $4 \mathrm{~s}$ ), les toiletteuses patrouillent et palpent les autres abeilles présentes autour d'elles. La phase de patrouillage dure environ $3 \mathrm{~s}$ (fig 1 ). Près de la moitié $(44,6 \%)$ du temps de toilettage est consacrée au nettoyage de la région des ailes (fig 2), $18 \%$ à la région du pétiole et durant $18 \%$ elles se nettoient ellesmêmes (fig 2). Les toiletteuses ne passent que $2,8 \%$ du temps total à nettoyer les sternites abdominaux des receveuses. Aucune tentative d'élimination des varroas n'a été observée au cours du comportement de toilettage social d'A m carnica.

\section{Apis mellifera carnica / comportement social / toilettage / danse de toilettage / ectoparasite / Varroa jacobsoni}

\footnotetext{
Zusammenfassung - Quantitative Analyse des sozialen Putzens bei der Honigbiene Apis mellifera carnica. Das soziale Putzen wird als ein wesentlicher Bestandteil der Arbeitsteilung im Bienenvolk angesehen (Kolmes und Winston, 1988; Seeley und Kolmes, 1991). Durch dieses Verhalten können Bienen der Art A cerana Varroamilben von ihren Nestgenossen entfernen (Peng, 1988; Büchler et al, 1992). Wir untersuchten, ob auch Apis mellifera carnica Varroamilben durch soziales Putzen entfernen. Die Reize, die das Körperputzen ausiösen, und die Dauer der Putzhandlungen wurden erfasst. Das soziale Putzverhalten wurde mit einer Videokamera aufgenommen und durch normale Wiedergabe oder Einzelbildauswertung analysiert. Das soziale Kör-
} 
perputzen setzt sich aus zwei Anteilen zusammen, der Annäherung einer Putzbiene an eine mögliche Empfängerbiene und der eigentlichen Putzhandlung. Ein Putzangebot wurde dadurch angenommen, daß die Empfängerbiene eine Putzaufforderungshaltung mit rechtwinklig zur Körperachse abgespreizten Flügeln einnahm. Oft wurden Bienen, die sich anfangs selbst putzten und daraufhin den Putztanz ausführten, von den Putzbienen aufgesucht. Während des Putztanzes schwenkten und verdrehten die Bienen ihren Körper. Die Putztänze wurden gelegentlich auch von müßigen oder patrouillierenden Bienen ausgeführt. Die häufigste Verhaltensfolge bestand aus: müssig oder patrouillieren $\longrightarrow$ Selbstputzen $\rightarrow$ Putztanz $\longrightarrow$ Putzaufforderung (Tabelle I). Die Dauer einer solchen typischen Putztanzsequenz betrug 6,5 bis $12 \mathrm{~s}$ (Median). Die Bienen putzten ohne Unterbrechung hintereinander bis zu 8 Stockgenossinnen. Zwischen zwei aufeinanderfolgenden Putzannäherungen (Median $4 \mathrm{~s}$ ) patrouillierten die Putzbienen und befühlerten andere Bienen in der Umgebung. Die Patrouillierphasen dauerten ungefähr $3 \mathrm{~s}$ (Abb 1). Während $44,6 \%$ der Putzzeit putzten die Bienen die Flügelregionen (Abb 2), 18\% der Zeit die Petiolusregion und weitere $18 \%$ der Zeit den eigenen Körper (Abb 2). Die Putzbienen verwendeten nur 2,8\% der Putzzeit auf die Reinigung der Abdominalsternite der Empfängerbienen. Während des sozialen Putzverhaltens von Apis mellifera carnica wurde keinerlei Versuch beobachtet, Varroamilben zu entfernen.

\section{Apis mellifera carnica / Putzverhalten / soziales Verhalten / Putztanz / Ekto- parasite / Varroa jacobsoni}

\section{REFERENCES}

Blom J (1990) Division of labour within one age group of honeybee workers (Apis mellifera). Actes Coll Insect Soc 6, 139-145
Boecking O, Rath W, Drescher W (1993) Grooming and removal behavior - strategies of Apis mellifera and Apis cerana bees against Varroa jacobsoni. Am Bee $J 133,117-119$

Büchler R, Drescher W, Tornier I (1992) Grooming behaviour of Apis cerana, Apis mellifera and Apis dorsata and its effect on the parasitic mites Varroa jacobsoniand Tropilaelaps clareae. Exp Appl Acarol $16,313-319$

Haydak MH (1929) Some new observations of the bee life. Cesky Vcelar 63, 229-231

Kolmes SA (1989) Grooming specialists among worker honey bees Apis mellifera. Anim Behav 6, 10481049

Kolmes SA, Winston ML (1988) Division of labour among worker honey bees in demographically manipulated colonies. Insectes Soc 35, 262-270

Milum VG (1947) Grooming dance and associated activities of the honey bee. II Acad Sci Trans 40, 194196

Moosbeckhofer R (1992) Observations on the occurrence of damaged Varroa mites in natural mite fall of Apis mellifera carnica colonies. Apidologie 23, 523531

Peng YS (1988) The resistance mechanism of the Asian honey bee (Apis cerana) to the mite Varroa jacobsoni. In: Africanized Honey Bees and Bee Mites (GR Needham, RE Page Jr, M Delfinado-Baker, CE Bowman, eds) Ellis Horwood Limited, Chichester, USA, 426-429

Ritter W, Schneider-Ritter U (1988) Differences in biology and means of controlling Varroa jacobsoni and Tropilaelaps clareae, two novel parasitic mites of Apis mellifera. In: Africanized Honey Bees and Bee Mites. (GR Needham, RE Page Jr, M DelfinadoBaker, CE Bowman, eds) Ellis Horwood Limited, Chichester, USA, 387-395

Ruttner F, Hänel H (1992) Active defense against Varroa mites in a Carniolan strain of honeybee (Apis mellifera carnica Pollmann). Apidologie 23, 173187

SAS Institute Inc (1988a) SAS Procedures Guide, Release 6.03 Edition. Cary, NC, USA, SAS Institute Inc 1-441

SAS Institute Inc (1988b) SAS/STAT User's Guide, Release 6.03 Edition. Cary, NC, USA, SAS Institute Inc 1-1028

Seeley TD, Kolmes SA (1991) Age polyethism for hive duties in honey bees - illusion or reality? Ethology 87 , 284-297

Snodgrass RE (1956) Anatomy of the Honey Bee. Cornell University Press, Ithaca NY, USA

Wallner A (1989) Auf der Suche nach der varroaresistenten Biene. Bienenwelt 31, 257-259

Winston ML (1987) The Biology of Honey Bee. Harvard University Press, Cambridge, MA, USA 